\title{
LEADERSHIP MANAGEMENT OF EDUCATION AND PERSONALITY LEADERS OF INDUSTRIAL REVOLUTION 4.0
}

\author{
Demina $^{1}$, Zulmuqim², Marhen ${ }^{3}$, Syaiful Marwan ${ }^{4}$ \\ Faculty of Tarbiyah and Teacher Training IAIN Batusangkar \\ Korespondensi: Jl. Jenderal Sudirman No.137, Kuburajo, Lima Kaum, Batusangkar, West Sumatra 27213 \\ e-mail: demina@iainbatusangkar.ac.id
}

\begin{abstract}
The industrial revolution 4.0 opened the eyes of every leader to fundamentally change, in every aspect of life. Changes and effects of the 4.0 revolution on education, progress and improvement in the quality and personality of its leaders. The development of science and technology undeniably influences the process of school organization in producing outputs that are ready to compete in the world of big data and discruptions. Responding to the challenges of the digital age, leaders need to prepare capable and skilled human resources, able to solve problems, communicate and collaborate with all lines. Teachers must get out of the mindset and safety zone for the learning process in an alldigital era and the principal is prepared externally and internally to adjust to the development of the industrial era 4.0 and distribution. The leader's personality is the total ethical appearance in leading and communicating and socializing with members of the organization.
\end{abstract}

Keywords: management, leadership, leader personality, industrial era 4.0

\section{PENDAHULUAN}

Kepemimpinan pendidikan era 4.0 dasar untuk kemajuan lembaga yang bersinergis dengan perubahan dan sikap kerja atau personality sebagai pemimpinan digital. Pimpinan mendorong personil berada dalam perubahan. Apabila kondisi lingkungan berubah begitu cepat terabaikan mengkibatkan organisasi mengalami kemunduran dan akses untuk kemajuan menjadi terhambat. Era 4.0 pemimpin mengambil keputusan berdasarkan data, transparan dan realitime.

Kemampuan kepala sekolah sebagai pemimpin masih kurang memadai hasil survey departemen pendidikan dan kebudayaan $70 \%$ dari 250 ribu kepala sekolah kurang kompeten dalam menjalankan tugas. Menurut Direktorat peningkatan mutu pendidikan dan tenaga Kependidikan Departemen Pendidikan, kepala sekolah lemah dalam bidang manjerian dan supervisi pendidikan. (Riadi)

Menurut (Syahadah 2018) lemahnya kemampuan kepemimpinan, dan kemampuan softskill kepala sekolah sebagai pemimpin dan manajer, mengelola sekolah dengan tangguh berhati lembut dan berwibawa. Dikutip dari Andrew Tani 2018 menyatakan tantangan atau gangguan pemimpin di era 4.0 yaitu tantangan eksternal dan internal integration menggerakan organisasi.

Era industri 4.0 pemimpin pendidikan sangat menentukan kemajuan dan mutu sekolah. Pemimpin memegang posisi 
dominan dalam bidangnya untuk melakukan kontrol, mempengaruhi, melakukan tindakan, keputusan, mempengaruhi untuk berinovasi menjadi agen perubahan ( Surahman 2015, Bennis dan Nanus 1985, Fairholm 2002). Menurut Aoun (2017), Nasir (2018) untuk mendapatkan SDM yang kompetitif dalam industri 4.0. kurikulum pendidikan harus dirancang agar out put-nya mampu menguasi literasi baru

\section{KAJIAN PUSTAKA}

\section{Manajemen Kepemimpinann}

Kepemimpinan didefinisikan sebagai sebuah proses bagi seseorang untuk melakukan perubahan dan peningkatan dalam suatu organisasi dengan mempengaruhi orang lain atau proses dalam organisasi. Pada teori kepemimpinan kontemporer, kepemimpinan adalah proses sosial yang dinamis yang dilihat berdasarkan kualitas individu (Antes et al., 2016: 2).Menurut Zaccaro (2014) bahwa dalam teori kepemimpinan, pemimpin sebagai ahli, pemecah masalah, dan pembantu pengikut dalam memenuhi kebutuhan hidupnya. Sedangkan manajemen didefinisikan sebagai proses bagi seseorang yang memegang peranan administratif formal dalam sebuah organisasi (Hallinger, 2018: 3). Banyak literatur membahas mengenai kepemimpinan dan manajemen kemudian mendefinisikannya sebagai mekanisme sosial di mana orang mencapai kesuksesan melalui upaya kolektif. Menurut Kanki(2019: 116) kepemimpinan yang efektif mencakup pada pemimpin yang menegaskan atau menguraikan aturan, norma, batasan tugas yang merupakan model normatif dan lingkungan tugas organisasi. pemimpin harusnya menetapkan dinamika otoritas yang jelas, serta kompetensi teknis, sosial, dan manajerial serta diperlukan bentuk pengaruh hirarkis dan distribusi kerja(Bush \& Glover, 2016: 6).

Dalam penyelidikan literatur, secara umum sebuah kepemimpinan memiliki tiga bentuk yaitu Pertama, autocratic yaitu sistem kepemimpinan dengan otoritas pusat atau figur pemimpin yang kuat. Kepemimpinan otokratis secara efektif dapat menyelesaikan

dilema sosial dengan memaksa anggota untuk berinvestasi dalam kelompok akan tetapi anggota mungkin akan kurang berkomitmen karena pemimpin hanya memberi sedikit kesempatan untuk menyuarakan pendapat (Van Vugt et al.,

2004: 2-3); Kedua, democratic yang dikenal sebagai bentuk pemerintahan oleh rakyat di mana kekuasaan dan tanggung jawab sipil dijalankan oleh semua warga negara dewasa secara langsung atau tidak langsung melalui perwakilan yang dipilih secara bebas. Dianggap hampir secara universal sebagai bentuk kepemimpinan yang baik (Klein et al., 2011: 2-3); Ketiga, free-rein gaya ini, pemimpin memberikan kemerdekaan penuh kepada bawahan dalam operasi mereka. Dia memungkinkan mereka untuk menetapkan tujuan mereka sendiri dan untuk mencapainya. Dengan kata lain, gaya ini melibatkan kebebasan penuh untuk

keputusan kelompok atau individu tanpa partisipasi minimum dari pemimpin. Satusatunya tugasnya adalah menyediakan berbagai bahan dan informasi yang diminta oleh bawahan (Marume \& Jaricha, 2016: 74).

Seperti halnya sebuah organisasi yang memiliki struktur, dunia pendidikan seperti sekolah juga memiliki sistem kepemimpinan dan manajemen kepemimpin yang banyak dibahas di mana kepemimpinan dan manajemen pendidikan pertama kali muncul 
sebagai bidang penyelidikan formal di Amerika selama pertengahan abad ke-20 (Hallinger \& Chen, 2014: 3). Kepemimpinan pendidikan sebagai praktik mempengaruhi orang lain untuk mencapai tujuan dalam konteks pendidikan dapat dipandang sebagai suatu sistem, yang memiliki tujuan/dasar pemikiran, membutuhkan input/sumber daya, memiliki proses, mencapai hasil dan berlangsung dalam lingkungan / konteks (Connolly et al., 2017: 7). Sejarah, budaya, pengaruh dan ketidaksadaran, secara paradoks kita menemukan pengaruhpengaruh lokal dan bernuansa spesifik pada praktik kepemimpinan yang umumnya diabaikan (Western, 2019: 371). Penelitian yang dilakukan Bush (2018: 3-4) tentang manajemen kepemimpinan pendidikan yang menekankan pada hirarki dengan akuntabilitas vertikal, pembagian kerja berdasarkan pada pengetahuan spesialis, aturan dan peraturan yang ketat dan hubungan impersonal yang sifatnya sangat formal. Hal ini didukung oleh hanya sedikit studi yang menyelidiki efek kepemimpinan pada sikap guru seperti kepuasaan kerja, komitemen, stres dan status dalam organisasi dan fokus yang lebih besar tentang bagaimana kepemimpinan dan manajemen memengaruhi kinerja guru.

Dalam sebuah kepemimpinan selain sisi manajemen yang harus diperhatikan juga adalah kepribadian seorang pemimpin karena pemimpin sangat potensial untuk mempengaruhi perilaku karyawan dan organisasi yang disebut sebagai efektivitas kepemimpinan agar dapat mencapai tujuan organisasi di mana penilaiannya dilakukan oleh atasan, rekan kerja, atau bawahan (Judge, 2002: 767). Kepribadian sebagai pemikiran dan perilaku yang konsisten dari seorang individu yang stabil dari waktu ke waktu dan relatif konsisten dalam berbagai situasi (Ozbag, 2016: 237). Kepribadian dan kepemimpinan merupakan hal yang saling berkait karena faktor kecerdasan sosial politik pemimpin, kemampuan untuk memahami dinamika politik kelompok dan sejauh mana pemimpin dipandang memiliki integritas (Hogan \& Judge, 2013: 37). Selain itu, nformasi kepribadian dapat diperoleh pada tiga tingkatan: 1) sifat disposisi; 2) adaptasi karakteristik (mis., motif, tujuan, dan nilai-nilai); dan 3) kisah hidup yang integratif (Hamid et al., 2016: 167).Ciri-ciri kepribadian tertentu berhubungan positif dengan efektivitas pemimpin dan kinerja tim. Ciri-ciri kepribadian ini meliputi pembedahan, stabilitas emosi, kesadaran, dan kesesuaian. Secara khusus, individu mencirikan pemimpin yang mirip dengan diri sebagai ideal (Marsiglia, A. J. (2005: 10-12).

Kepemimpinan merupakan proses saling mempengaruhi (Umam,2014) aktivitas organisasi dalam mencapai tujuan bersama yang telah ditetapkan. (Thoyib,2005) kepemimpinan adalah kekuatan dari dalam diri untuk mempengaruhi anggota dalam mencapai tujuan bersama. Kepemimpinan adalah suatu kemapuan untuk mengarahkan dalam pencapaian tujuan bersama Annizah, Maretta (2017) Menurut Moejiono (2002) fungsi kepemimpinan yaitu fungsi administrasi untuk memfasilitasi berbagai kebutuhan organisasi, fungsi sebagai top manajemen dalam kegiatan planing, organizing, staffing, directing, commanding, dan controlling. Kepemimpinan adalah konsep yang kompleks sehingga suatu definisi yang pasti akan sulit didapat. (Rost. 1991) kepemimpinan adalah prilaku individu untuk mengarahkan aktifitas kelompok, memobilisasi sumber daya institusional, politis, psikologis dan sumber lain, 
memberikan arahan, usaha bersama mencapai tujuan melalui proses inovasi ( Hemphill\&coons.1957, Katz \&kahn 1978. Burns 1978, Rauch\&Behling.1984. Jacop \& Jaques 1990

Kepemimpinan kepala sekolah merupakan pendorong dan pelaksanaan pengelolaan sekolah. Ahmad (2016). Pemimpim atau kepala sekolah selalu mendorong pencapaian yang diharapan dalam era industri 4.0 yaitu Keterampilan bagi peserta didik era industri 4.0 antara lain 1) keterampilan berpikir kritis. 2). Kreatif dan inovatif. 3) keterampilan komunikasi dan kolobarasi, 4) keterampilan mencari, mengelola, dan menyampaikan informasi. 5) keterampilan menggunakan media informasi dan teknologi 6) global Citizenship 7) Career \& life skill. ( Sutilistiyanto, Edhy Aruman, Pratikno. 2019) Dari beberapa keterampilan yang diharapkan pada abad 21 akan mempengaruhi/menggangu proses pembelajaran yang disebut dengan distruptive learning yaitu 1) distruptive learning berkaitan erat dengan trasformative learning (Mezirow 2009, \& Reeducation (Lewin 1948) pengefektifan perubahan, terutama dalam hal merubah framwork berfikir (minset) pembelajaran yang aktif melalui proses paedagogik dimungkinkan adanya penelaahan secara mendalam berbagai perspektives, values dan worldviews. Menuju kemampuan belajar yang sustainabel. Untuk pencapaian diatas tentu pemimpin menggunakan manajemen yang baik sesuai dengan fungsinya yaitu merencanakan, mengorganisasi, menemptkan, mengkoordinasikan, mengontrol.

Pemimpin sekolah betul-betul melakukan fungsi manajemen di atas dalam meningkatkan mutu lembaga yang dipimpinnya. Reitz 1981. Pemimpin dalam memimpin juga dipengaruhi oleh faktorfaktor seperti: 1) Kepribadian (personality) . 2) Harapan dan perilaku atasan, 3) karakeristik, 4) kebutuhan tugas. 5) Iklim dan kebijakan organisasi mempengaruhi harapan dan perilaku bawahan dan harapan dan perilaku rekan. Faktor- faktor di atas akan mempengaruhi kepemimpinan seseorang era industri 4.0. Sifat kepribadian /personality didefinisikan sebagai keseluruhan cara seseorang bereaksi dan berinteraksi dengan lingkungan ataupun individu. Ada Model lima besar atau big five personality traist model yang dikenalkan oleh lewis yaitu opennes, conscientiousness, extraversion/introversion, agreeblenes atau di singkat dengan OCEAN. Kepemimpinan era 4.0 harus pintar-pintar melihat SDM yang ada disekitar sesuai dengan cir-ciri persolaity seperti terbuka terhadap hal-hal yang baru hal ini diperkuat oleh pidato presiden Jokowi bahwa semua masyarakat Indonesia harus keluar dari kondisi aman. Selanjut sifat berhati-hati (conscientiousness) pemimpin harus berhati-hati dalam melakukan sustu tindakan, pertimbangan dalam mengambil keputusan, disiplin kerja yang tinggi serta dapat dipercaya

\section{Kepribadian Pemimpinan}

Personality atau sikap kepribadian dan tindak tanduk pemimipin dalam era 4.0 mampu memberikan sentuhan baik secara langsung maupun tidak langsung dalam suatu oragnisasi. Personaliti pendidikan adalah sikap seseorang secara totalitas sebagai kepbribadian yang tangguh dalam berkomunikan, pembawaan diri dan pemikirannya. Walidin.(2016), Ghani (2002) personality yang baik merupakan keagungan seseorang dalam kebolehan bergaul sopan santun dan kelembutannya. 
Secara umum, kepribadian dalam kepemimpinan Big Five Personality yang terdiri dari (1). Extraversion, ketika pemimpin itu kreatif, dia dapat mengubah orang dan organisasi untuk mendorong ke visi yang dia menginspirasi. Dia akan mendorong pengikut untuk mengekspresikan ide tentang bagaimana menyelesaikan masalah yang dihadapi organisasi; (2). Agreeableness, keramahan sebagai tingkat di mana seseorang dapat bergaul dengan orang lain dengan bersikap baik, kooperatif, pemaaf, penyayang, pengertian, dan kepercayaan; (3). Conscientiousness, kesadaran sebagai tingkat dimana seseorang bertanggung jawab, dapat diandalkan, gigih, dan berorientasi pada prestasi. Seseorang yang berhati nurani terfokus pada beberapa tujuan, yang dikejar dengan cara yang disengaja; (4). Neurotic, seorang pemimpin yang stabil secara emosional menangani stres dengan baik, mampu menangani kritik, dan umumnya tidak mengambil kesalahan dan kegagalan secara pribadi. Mereka umumnya memiliki kepercayaan diri yang lebih rendah dan mungkin meledak dalam ledakan emosi ketika stres atau dikritik; (5). Openness, orang yang terbuka adalah seseorang yang memiliki minat luas dan imajinatif, kreatif, dan mau mempertimbangkan ide-ide baru. Orangorang ini secara intelektual ingin tahu dan sering mencari pengalaman baru melalui perjalanan, seni, film, membaca secara luas, atau kegiatan lainnya. (Yahaya et al, 2011: 9641-9642; Alkahtani et al., 2011: 74-75; Aidt, T., \& Rauh, C. (2018: 3)

\section{Menurut Al-Qar'an}

mengemukakan ciri-ciri personality atau sahsiah sebagai berikut: a) mampu memberi pertolongan kepada orang lain, b) semangat serta kepercayaan untuk meningkatkan tingkah laku manusia, c) mampu memberi gambaran hubungan secara saintifik dalam proses kemasyarakatan, d) bertanggung jawab dalam ruang lingkup pekerjaan, e) selalu melakukan hal yang benar dan selamat. Selanjutnya Shamsuddin (1989) juga mengemukakan karakteristik personality antara lain: consistency, sikap konsisten dalam berbagai situasi, b) Psychologycal , sikap psikologis yang datang dari dalam diri seseorang, c) tindakan dan respon seseorang berdasar kepribadian, d) ekspresi atau aura dan bahasa tubuh dalam bersosialisasi. berbagai ciri dan karakteristik personality seseorang menggambarkan sikap atau keribadian pemimpin masa kini dalam era industri 5.0. dunia yang diselimuti dengan berbagai kecanggihan teknologi membuat pemimpin lebih memahami sikap anggota yang dipimpinnya memalui sentuhan dan komunikasi tanpa batas.

Kepala sekolah sebagai pemimpin era industri 4.o perlu mengevaluasi dan mengontrol tim bersama-sama, feeback atau masukan secara konstan dan terintegrasi secara internal dan eksternal juga harus berani mau menerima, mendorong dan memotivasi tim untuk memberikan masukan terhadap kepemimpinan demi kemajuan bersama serta memilih dan mengembangkan talenta.

Pendidikan era 4.0 kepala sekolah menyiapkan pertama siswa tidak hanya disiapkan dalam penguasaan TIK tetapi juga mampu berpikir kritis, memecahkan masalah, berkomunikasi dan kreatif serta mampu berkolaborasi. Kedua Mindset guru perlu diubah untuk mampu beradaptasi dengan TIK dalam pembelajaran. Ketiga sekolah harus mrmanfaatkan TIK mulai dari input, proses belajar dan evaluasi, dapodik, ujian sekolah. Ujian nasional berbasis komputer dan E-Rapor. Pemimpin itu sendiri juga dapat menantang dirinya untuk lebih maju, memahami dunia teknologi informasi yang sangat pesat supaya 
pemimpin bisa keluar dari zona aman. (yudi candra 2018.)

Otto menjelaskan dalam menghadapi tantangan 4.0 masyarakat dituntut untuk melihat sepenuhnya ( open mind), mengerti sepenuhnya ( openheart), menerima sepenuhnya (open will) kepala sekolah sebagai ASN berkolaborasi untuk menciptakan tata kelola 4.0 Awereness Based Collective $(\mathrm{ABC})$ atau pemerintahan yang transparan dan akuntabel (open Goverment and Open Data) berdasarkan eco-system atau kebutuhan masyarakat dimana kepala sekolah merupakan pelayan masyarakat.

\section{PEMBAHASAN}

Manajemen kepemimpinan yang terdiri dari lima aspek salah satu dari kelima saling mengisi dan terkait diantaranya perencanaan, pelaksanaa, pengorganisasian, kontrol dan evaluasi. Terkait dengan era revolusi 4.0 satu diatara aspek yang ada sangat menentukan kemajuan pendidikan dan organisasi. Apabila satu diantara lima aspek yang ada menjadi lemah dan terabaikan pada era 4.0 tentu membawa dampak yang sangat besar terhadap kemajuan dan mutu organisasi. Untuk menghadapi kondisi pada era 4.0 pemimpin hendaklah berpikir dan bertindak cepat dari sistem perubahan yang terjadu begitu cepat. Salah satu kunci dalam menghadapi era 4.0 adalah keahlian dan agility dari pemimpin yang sangat menentukan kesuksesan pemimpin.

Kepribadian dan karakter pemimpin yang utama perlu dimiliki seorang pemimpin yaitu berpindirian teguh, jujur, proaktif, fleksibel, komunikatif, berpikiran terbuka, cerdas, percaya diri, antusias, teratur, evaluatif dan penuh penghargaan. Tulisan (Keith davis) juga menyoroti kepribadian pemimpin yaitu memliki kedewasaan dan keluasan pandangan sosial. Kedewasaan untuk menyelesaikan masalah sosial serta bisa menerima kritikan dan memberikan masukan, senjutnya pemimpin mempunyai motivasi dan dorongan berprestasi untuk mencapai tujuan bersama.

Menjadi pemimpin era 4.0 memiliki sikap dan kapasitas menjadi pemimpin problem solver dalam permasalahan yang dihadapi anggota organisasi sekolah. persoalan sekolah dalam era 4.0 dengan gangguan yang berasal dari guru, siswa dan lingkungan. Disini peran poblem solver pemimpin meupakan hal yang sangat menentukan kemajuan oraganisasi. Selain sebagai problem solver juga mampu menjadi dicision maker serta untuk mengambil keputusan yang tepat dan bijak. Kemampuan yang sangat sulit sekalipun perlu dihayati dan dipahami pemimpin sepeti pepatah minang ibarat menarik rambut dalam tepang. Rambut jangat putus dan tepung jangan sampai berserak. Berbagai teori dan konsep mampu menjawab berbagai kebutuhan kepemimpinan pada era 4.0 mempunyai kompetensi pemimpin yang efektif dan juga memiliki skill menurut White (1997) meliputi, difficult learning, maximizing energy, resonant simplicity dan multiple focuses serta mastering inner sense. (Purnama, 2000)

Berbagai konsep tentang manajemen kepemimpinan dan kepribadian pemimpin pendidikan era 4.0, merupakan konsep yang tak habis dan hentinya untuk di kaji dan dibahas. Tulisan ini mempunyai kelemahan dan mengupas konsep yang baru hanya pada tataran konsep secara deskriptif. Kelemahan juga pada tulisan ini yaitu belum diangkat dari hasil penelitian yang betul-betul dilaksanakan terhadap pemimpin hari. bagaimana manajemen kepemimpinan di lapangan dalam era 4.0 yang semesti dan sesungguhnya. 
Saran penulis untuk konsep yang sedang hangat dan tidak bisa dielakkan hari ini untuk dilanjutkan dalam penelitian - penelitian lapangan dan sesungguhnya. Manajamen kepemimpin sekolah selalu hendaknya mengutamakan kemajuan siswa dan pendidikan yang bermutu untuk kemajuan anak bangsa. Serta pemimpin kepribadian pemimpin hari ini betul-betul harus tangguh, visioner dengan akhlak yang mulia, komunikatif tidak egois dan berkolaborasi dengan semua lini dan anggota organisasi yang ada.

\section{PENUTUP}

\section{Kesimpulan}

Dapat disimpulkan bahwa Revolusi Industri 4.0 memberikan berbagai peluang kepada setiap orang yang memimpin untuk mengikuti dan melakukan perubahan secara fundamental. Berbagai hal dapat dikreasikan oleh masing-masing pemimpin dengan melihat banyaknya pilihan di dalam proses mengelola kepempinannya tersebut. Dengan banyaknya pilihan tersebut menyebabkan perubahan yang fundamental bagi setiap pemimpin terutama dibidang pendidikan. Adanya perkembangan IPTEK yang merupakan tanda terbuka sistem informasi dan berkembangnya ilmu pengetahuan mendorong pemimpin pendidikan untuk bergerak dalam membenahi kepemimpinan, baik dalam manajemen pendidikannya maupun membentuk karakter kepempimpinannya.

\section{Saran}

1. Saran pertama yang harus dimiliki pemimpin dalam menjalankan kepemimpinannya dalam pendidikan adalah kesiapsediaan pemimpin dalam menerima perubahannya

2. Dengan adanya perkembangan IPTEK, yang mampu mempengaruhi orang banyak, memang para pemimpin harus memiliki integritas yang kuat dalam menjalankan amanah.

3. Mampu berfikir rasional dalam melihat persoalan pendidikan secara selektif dan inovatif dalam menyelesaikan tugasnya terkait dengan kepemimpinannya.

4. Memiliki ilmu manajemen yang mendasar bukan hanya secara teoritis, tetapi juga secara implementatif di dunia pendidikan.

\section{KEPUSTAKAAN ACUAN}

Aidt, T., \& Rauh, C. (2018). The Big Five personality traits and partisanship in England. Electoral Studies, 54, 121. doi:10.1016/j.electstud.2018.04.01 7

Alkahtani, A. H., Abu-Jarad, I., Sulaiman, M., \& Nikbin, D. (2011). The impact of personality and leadership styles on leading change capability of Malaysian managers. Australian Journal of Business and Management Research, 1(2), 70.

Annizah dan Winnda Fitri Maretta . 2017. Jurnal. Manajemen, Kepemimpinan dan supervisi Pendidikan. Vol 2 no 1. Januari - Juni 2017

Antes, A. L., Mart, A., \& DuBois, J. M. (2016). Are Leadership and Management Essential for Good Research? An Interview Study of Genetic Researchers. Journal of Empirical Research on Human Research Ethics, 11(5), 408423. doi:10.1177/1556264616668775

Bush, T. (2018). Distributed leadership and bureaucracy: Changing fashions in educational leadership. Educational Management Administration \& Leadership, 47(1), 34. doi:10.1177/1741143218806704 
Bush, T., \& Glover, D. (2016). School leadership and management in South Africa. International Journal of Educational Management, 30(2), 211231. doi:10.1108/ijem-07-2014-0101

Connolly, M., James, C., \& Fertig, M. (2017). The difference between educational management and educational leadership and the importance of educational responsibility. Educational

Management Administration \& Leadership,

174114321774588. doi:10.1177/17411 43217745880

Hallinger, P. (2018). A systematic review of research on educational leadership and management in South Africa: mapping knowledge production in a developing society. International Journal of Leadership in Education, 119. doi:10.1080/13603124.2018.14634 60

Hallinger, P., \& Chen, J. (2014). Review of research on educational leadership and management in Asia. Educational Management Administration \& Leadership, 43(1), 527. doi:10.1177/1741143214535744

Hamid Hassan , Sarosh Asad, Yasuo Hoshino . "Determinants of Leadership Style in Big Five Personality Dimensions." Universal Journal of Management 4.4 (2016) 161 - 179. doi: 10.13189/ujm.2016.040402.

Hogan, R., \& Judge, T. (2013). Personality and leadership. The Oxford handbook of leadership, 37-46.

Judge, T. A., Bono, J. E., Ilies, R., \& Gerhardt, M. W. (2002). Personality and leadership: A qualitative and quantitative review. Journal of Applied Psychology, 87(4), 765780. doi:10.1037/0021-9010.87.4.765

Kanki, B. G. (2019). Communication and crew resource management. In Crew resource management (pp. 103-137). Academic Press.
Klein, A., Kiranda, Y., \& Bafaki, R. (2011). Concepts and Principles of Democratic Governance and Accountability.

Marsiglia, A. J. (2005). The relationship between leadership and personality. Saatavissa: http://leadinspire. com/PapersArticles/LeadershipManagement/The\% 20Relationship\% 20between $\%$ 20leadership $\%$ 20and $\%$ 20Personality. pdf.[Luettu 15.10. 2013].

Marume \& Jaricha. (2016). Styles of Leadership in Institutions. International Journal of Business and Management Invention, 5 (5), 72-77

Özbağ, G. K. (2016). The Role of Personality in Leadership: Five Factor Personality Traits and Ethical Leadership. Procedia - Social and Behavioral Sciences, 235, 235242. doi:10.1016/j.sbspro.2016.11.019

Van Vugt, M., Jepson, S. F., Hart, C. M., \& De Cremer, D. (2004). Autocratic leadership in social dilemmas: A threat to group stability. Journal of Experimental Social Psychology, 40(1), 1-13. doi:10.1016/s00221031(03)00061-1

Western, S. (2019). Leadership: A critical text. SAGE Publications Limited.

Yahaya, N., Taib, M. A. B. M., Ismail, J., Shariff, Z., Yahaya, A., Boon, Y., \& Hashim, S. (2011). Relationship between leadership personality types and source of power and leadership styles among managers. African Journal of Business Management, 5(22), 9635-9648.

Zaccaro, S. J. (2014). Leadership memes: From ancient history and literature to twentyfirst century theory and research. In D. V. Day (Ed.). The Oxford handbook of leadership and organizations (pp. 13-39). New York: Oxford. 